\title{
KEKUATAN HUKUM TRANSAKSI DAN TANDA TANGAN ELEKTRONIK DALAM PERJANJIAN
}

\author{
Titi S. Slamet ${ }^{1}$, Marianne Masako Paliling ${ }^{2}$
}

\begin{abstract}
Abstrak
Teknologi informasi diyakini akan menjadi alternatif utama bagi penyelenggaraan kegiatan bisnis maupun pemerintahan. Dengan memperhatikan dua hal tersebut, maka pemanfaatan teknologi informasi harus dilihat dalam dua kerangka pendekatan, yaitu dari aspek keberadaaan teknologi dan aspek hukumnya. Undang - Undang Republik Indonesia Nomor 11 Tahun 2008 tentang Informasi dan Transaksi Elektronik. Permasalahan yang dihadapi apakah tanda tangan elektronik mempunyai kekuatan hukum terutama dari segi pembuktian. Penelitian ini berlokasi di perpustakaan UNHAS kota Makassar, metode Penulisan ini bersifat yuridis normatif menggunakan studi pustaka (library research) dengan menggunakan analisis kualitatif. Undang-Undang Nomor 11Tahun 2008 tentang Informasi dan Transaksi Elektronik memberikan pengakuan secara tegas bahwa tandatangan elektronik memiliki kekuatan hukum dan akibat hukum selama tanda tangan elektronik mengikuti persyaratan yang disebutkan dalam Pasal 11 UU ITE yang merupakan persyaratan minimum dan harus dipenuhi dalam setiap pembuatan tanda tangan elektronik, tingkat keamanan dari tanda tangan elektronik akan terjamin keamanannya apabila mempunyai sertifikat elektronik berisi informasi atau identitas dari pengguna, Sertifikat elektronik diperoleh atas dasar aplikasi kepada Certification Authority (CA) oleh pengguna (subscriber).
\end{abstract}

Kata Kunci: Tanda Tangan, Perjanjian, Elektronik.

\section{PENDAHULUAN}

\subsection{Latar Belakang}

Teknologi informasi terus berkembang dengan sangat cepat dan semakin penting artinya bagi masyarakat. Penggunaan dan pemanfaatan teknologi informasi juga harus dikem-bangkan untuk menjaga, memelihara dan memperkukuh persatuan dan kesatuan nasional berdasarkan peraturan perundang-undangan demi kepentingan nasional.

Perkembangan pemanfaatan teknologi informasi, media dan komunikasi telah mengubah perilaku masyarakat maupun peradaban manusia secara global apalagi dengan hadirnya era internet yang memudahkan semua orang bisa mengakses dan mendapatkan informasi dengan mudah. Pemerintah perlu mendukung pengembangan teknologi informasi melalui infrastruktur hukum dan pengaturannya, sehingga pemanfaatan teknologi informasi dilakukan secara aman dan mencegah penyalahgunaannya dengan memperhatikan nilai-nilai agama dan sosial budaya masyarakat Indonesia. Teknologi informasi diyakini akan menjadi alternatif utama bagi penyelenggaraan kegiatan bisnis maupun pemerintahan. Dengan memperhatikan dua hal tersebut, maka pemanfaatan teknologi informasi harus dilihat dalam dua kerangka pendekatan, yaitu dari aspek keberadaaan teknologi dan aspek hukumnya. Undang-Undang Republik IndonesiaNomor 11 Tahun 2008 tentang Informasi dan Transaksi Elektronik adalah wujud pendekatan hukum dalam memberikan perlindungan maksimal kepada seluruh aktivitas pemanfaatan teknologi informasi dan komunikasi dalam negeri agar terlindung dengan baik dari potensi kejahatan dan penyalahgunaan teknologi. Dalam konsideran Undang-Undang Nomor 11 Tahun 2008 tentang Informasi dan Transaksi Elektronik, dinyatakan bahwa pembangunan nasional yang telah dilaksanakan pemerintah Indonesia dimulai pada era baru hingga orde saat ini, merupakan proses yang berkelanjutan yang harus senantiasa tanggap terhadap berbagai dinamika yang terjadi di masyarakat.

Dalam kegiatan bisnis untuk penyampaian informasi, komunikasi dan transaksi elektronik dalam menggunakan sistem elektronik. Sistem elektronik adalah serangkaian perangkat dan prosedur elektronik yang berfungsi mempersiapkan, mengumpulkan, mengolah,menganalisis, menyimpan, menampilkan, mengumumkan, mengirimkan dan menyebarkan informasi elektronik. Dan salah satu media elektronik yang dapat menggunakan sistem elektronik adalah komputer.

\footnotetext{
${ }^{1}$ Dosen Fakultas Hukum Universitas Kristen Indonesia Paulus Makassar

${ }^{2}$ Mahasiswa Fakultas Hukum Universitas Kristen Indonesia Paulus Makassar
} 
Sistem elektronik, digunakan untuk menjelaskan keberadaan sistem informasi yang merupakan penerapan teknologi informasi yang berbasis jaringan telekomunikasi dan media elektronik, yang berfungsi merancang, memproses, menganalisis, menampilkan, dan mengirimkan atau menyebarkan informasi elektronik. Setiap orang dapat memberikan informasi tentang segala hal, termasuk juga pemberian informasi terhadap penjualan suatu barang atau jasa dengan menggunakan teknologi informasi ini, dari informasi tersebut, apabila seseorang tertarik untuk memiliki suatu produk barang atau jasa yang ditawarkan tersebut, maka akan terjadi suatu transaksi elektronik.

Transaksi elektronik bersifat non face (tanpa bertatap muka), non sign (tidak memakai tanda tangan asli) dan tanpa batas wilayah (seseorang dapat melakukan transaksi elektronik dengan pihak lain walaupun mereka berada di Negara yang berbeda) dengan menggunakan teknologi informasi. Penggunaan informasi elektronik ini menggunakan jaringan publik, dimana setiap orang dapat mengetahui informasi elektronik tersebut. Sehingga bisa saja salah satu dari pihak yang bersangkutan tidak melaksanakan prestasi dari transaksi elektronik yang telah disepakati danmenimbulkan permasalah hukum yang merugikan pihak lain yang mempunyai kepentingan yang menggunakan teknologi informasi untuk penjualan suatu barang dan jasa.

Permasalahan hukum yang sering kali dihadapai adalah ketika terkait dengan penyampaian informasi, komunikasi, maupun transaksi secara elektronik, khususnya dalam hal pembuktian dan hal yang terkait dengan perbuatan hukum yang dilaksanakan melalui sistem elektronik. Hingga saat ini hukum positif Indonesia masih menentukan bahwa hanya satu cara untuk memberikan kekuatan hukum dan akibat hukum terhadap suatu akta, yaitu dengan tanda tangan manuskrip. Namun dalam praktek perdagangan khususnya dalam sistem perdagangan elektronik (E-commerce) menggunakan tanda tangan elektronik yang melekat pada akta elektronik sehingga timbul perdebatan tentang pengakuan, kekuatan hukum dan akibat hukum dari sebuah tanda tangan elektronik. Sehingga jika para pihak setuju dalam perjanjian yang disepakati para pihak bagaimana kedudukan dan kekuatan hukum dari tanda tangan elektronik serta tingkat keamanan bagi konsumen dalam transaksi elektronik.

\subsection{Rumusan Masalah}

1. Bagaimanakah kedudukan dan kekuatan hukum dari tandatangan elektronik dalam perjanjian?

2. Bagaimana tingkat keamanan bagi konsumen terhadap penggunaan tanda tangan elektronik dalam transaksi elektronik?

\subsection{Tujuan Penelitian}

1. Untuk mengetahui bagaimana kekuatan hukum dari tanda tangan elektronik dalam pembuatan perjanjian.

2. Untuk mengetahui tingkat keamanan tanda tangan elektronik dalam transaksi elektronik.

\section{LANDASAN TEORI}

\subsection{Pengertian Perjanjian}

Perjanjian adalah suatu peristiwa dimana seseorang berjanji kepada pihak lain atau dimana dua orang itu saling berjanji untuk melaksanakan suatu hal.Melalui perjanjian terciptalah perikatan atau hubungan hukum yang menimbulkan hak dan kewajiban pada masing-masing pihak yang membuat perjanjian tersebut. Dalam hal ini fungsi perjanjian sama dengan perundang-undangan tetapi hanya berlaku khusus terhadap para pembuatnya saja. Hukum memberikan sanksi terhadap pelaku pelanggaran perjanjian atau ingkar janji (wanprestasi).

Dalam ketentuanPasal 1313 KUHPerdata suatu perjanjian adalah suatu perbuatan dengan mana satu orang atau lebih mengikatkan dirinya terhadap satu orang lain atau lebih. Dari pengertian tersebut menggambarkan tentang adanya dua pihak yang saling mengikatkan diri dan timbulah suatu hubungan hukum perikatan yang di dalamnya terdapat hak dan kewajiban masing- masing pihak. Perjanjian adalah sumber perikatan.

\subsubsection{Syarat Sah-nya Perjanjian}

Untuk mengetahui apakah suatu perjanjian adalah sah atau tidak sah, maka perjanjian tersebut harus diuji dengan beberapa syarat. Terdapat empat syarat keabsahan kontrak yang diatur dalam ketentuan Pasal 1320 KUHPerdata, yang merupakan syarat pada umumnya, yaitu sebagai berikut:

a. Sepakat mereka yang mengikatkan dirinya 
Kesepakatan yang dimaksudkan adalah persesuaian kehendak antara para pihak, yaitu bertemunya antara penawaran dan penerimaan.Para pihak dalam persesuaian kehendak mengeluarkan pendapatnya tentang apa yang akan diatur dalam kontrak tersebut, sehingga suatu kontrak dapat dianggap sah oleh hukum.

b. Kecakapan untuk membuat suatu perikatan

Kecakapan adalah kemampuan menurut hukum untuk melakukan perbuatan hukum (perjanjian). Kecakapan ini ditandai dengan dicapainya umur 21 atau telah menikah walaupun usianya belum sampai 21 tahun.

c. Suatu hal tertentu

Suatu hal tertentu merupakan syarat ketiga untuk sahnya perjanjian untuk menerangkan tentang harus adanya objek perjanjian yang jelas. Jadi suatu perjanjian tidak dapat dilakukan tanpa objek yang tertentu. Dalam KUHPerdata suatu hal tertentu juga diatur dalam ketentuan Pasal 1333 yang menerangkan bahwa objek yang diperperjanjikan minimal sudah ditentukan jenisnya.

d. Suatu sebab yang halal

Merupakan syarat yang mengatur tentang isi perjanjian, dimana perjanjian yang dibuat tidak boleh bertentangan dengan peraturan perundang-undangan, kesusilaan dan ketertiban umum. Apabila dalam isi perjanjian yang dibuat bertentangan dengan hal yang disebutkan maka perjanjian tersebut tidak mempunyai kekuatan dan dapat batal demi hukum.

\subsubsection{Teori Kesepakatan dalam perjanjian}

Sebagai salah satu syaratsah-nya suatu perjanjian, kesepakatan memegang peran penting dalam proses terbentuknya suatu perjanjian. Adapun teori - teori tentang kesepakatan dalam perjanjian yaitu

a. Teori Penawaran dan penerimaan (offer and acceptance) merupakan teori dasar dari adanya kesepakatan kehendak adalah teori "penawaran dan penerimaan". Yang dimaksudkan adalah bahwa pada prinsipnya suatu kesepakatan kehendak baru terjadi setelah adanya penawaran (offer) dari salah satu pihak dan diikuti dengan penerimaan lamaran (acceptance) oleh pihak lain dalam kontrak tersebut. Teori ini diakui secara umum di setiap sistem hukum, sungguhpun pengembangan dari teori ini banyak dilakukan di negara- negara yang menganut sistem hukum common law.

b. Teori Kehendak (wils theorie). Teori ini mengajarkan bahwa kesepakatan terjadi pada saat kehendak pihak penerima dinyatakan, misalnya dengan menuliskan surat.

c. Teori Pengiriman (verzend theorie).Menurut teori pengiriman ini, suatu kesepakatan terjadi pada saat kehendak yang dinyatakan itu dikirim oleh pihak yang menerima tawaran. Dengan kata lain suatu kata sepakat terbentuk pada saat dikirimnya surat jawaban oleh pihak yang kepadanya telah ditawarkan suatu kontrak, karena sejak saat pengiriman tersebut, si pengirim jawaban telah kehilangan kekuasaan atas surat yang dikirimnya itu.

d. Teori Pengetahuan (vernemings theorie) adalah pengetahuan dari pihak yang menawarkan. Jadi menurut teori ini suatu kata sepakat dianggap telah terbentuk pada saat orang yang menawarkan tersebut mengetahui bahwa penawarannya itu telah disetujui oleh pihak lainnya. Jadi teori ini pada hakikatnya mengajarkan bahwa pihak yang menawarkan seharusnya sudah mengetahui bahwa tawarannya diterima.

e. Teori kepercayaan (vertrouwens theorie). Teori ini mengajarkan bahwa kesepakatan itu terjadi pada saat pernyataan kehendak dianggap layak (secara objektif) diterima oleh pihak yang menawarkan.

f. Teori kotak pos (mail box theorie). Menurut teori ini suatu penerimaan tawaran dari suatu kontrak sehingga kontrak dianggap mulai terjadi, adalah pada saat surat jawaban yang berisikan penerimaan tersebut dimasukkan dalam kotak pos.

g. Teori ucapan (uiting theorie). Menurut teori ini bahwa suatu kesepakatan kehendak terjadi bila pihak yang menerima penawaran telah menyiapkan surat jawaban yang menyatakan bahwa dia telah menerima tawaran tersebut.

h. Teori Dugaan. Menurut teori ini saat tercapainya kata sepakat sehingga saat itu juga dianggap sebagai saat terjadinya suatu kontrak adalah pada saat pihak yangmenerima tawaran telah mengirim surat jawaban dan dia secara patut dapat menduga bahwa pihak lainnya (pihak yang menawarkan) telah mengetahui isi surat itu.

\subsubsection{Asas Dalam Hukum Perjanjian}


Asas merupakan dasar-dasar (bersifat umum) yang terdapat dalam setiap sistem hukum yang terjelma dalam peraturan perundang-undangan dan putusan hakim yang merupakan hukum positif dan asas ini mengandung nilai-nilai etis yang diakui oleh suatu masyarakat. Di dalam hukum perjanjian terdapat beberapa asas sebagai berikut:

a. Asas Konsensualisme

b. Asas Kebebasan Berkontrak

c. Asas Kepercayaan

d. Asas Kekuatan Mengikat.

e. Asas Persamaan Hukum

f. Asas Keseimbangan

g. Asas Kepastian Hukum.

h. Asas Moral.

1. Asas Kepatutan

j. Asas Kebiasaan

\subsection{Transaksi Elektronik}

Transaksi elektronik adalah perbuatan hukum yang dilakukan dengan menggunakan komputer, jaringan komputer, dan/atau media elektronik lainnya. Pemanfaatan teknologi informasi dan transaksi elektronik dilaksanakan berdasarkan asas kepastian hukum,mmanfaat, kehati-hatian, iktikad baik, dan kebebasan memilih teknologi atau netral teknologi. Hal ini dilakukan untuk memberikan rasa aman, keadilan, dan kepastian hukum bagi pengguna dan penyelenggara teknologi informasi.

\subsubsection{Dasar Hukum Transaksi Elektronik}

Transaksi Elektronik diatur dalam Undang-Undang Nomor 11 Tahun 2008 tentang Informasi dan Transaksi Elektronik dari Pasal 17 sampai dengan Pasal 22. Kehadiran undang-undang ini memberikan manfaat berupa:

(1) Menjamin kepastian hukum bagi masyarakat yang melakukan transaksi elektronik.

(2) Mendorong pertumbuhan ekonomi.

(3) Sebagai salah satu upaya untuk mencegah terjadinya kejahatan berbasis teknologi informasi.

(4) Melindungi masyarakat pengguna jasa dengan memanfaatkan teknologi informasi.

Dalam ketentuan Pasal 1 ayat (2) Undang-Undang Nomor 11 Tahun 2008 Informasi dan Transaksi elektronik (ITE) pengertian Transaksi Elektronik adalah perbuatan hukum yang dilakukan dengan menggunakan komputer, jaringan komputer, dan/atau media elektronik lainnya. Perbuatan hukum penyelenggaraan transaksi elektronik dapat dilakukan dalam lingkup publik maupun privat. Para pihak yang melakukan transaksi elektronik wajib beriktikad baik dalam melakukan interaksi dan/atau pertukaran informasi elektronik dan/atau dokumen elektronik selama transaksi berlangsung.

Penyelenggaran transaksi elektronik ini diatur dengan Peraturan Pemerintah Nomor 82 Tahun 2012 dalam Pasal 17, yaitu:

(1) Penyelenggaraan transaksi elektronik dapat dilakukan dalam lingkup publik atau privat;

(2) Para pihak yang melakukan transaksi elektronik sebagaimana dimaksud pada ayat (1) wajib beriktikad baik dalam melakukan interaksi dan/atau pertukaran informasi elektronik dan/atau dokumen elektronik selama transaksi berlangsung;

(3) Ketentuan lebih lanjut mengenai penyelenggaraan transaksi elektronik sebagaimana dimaksud pada ayat (1) diatur dengan Peraturan Pemerintah.

Selain Undang-Undang Nomor 11 Tahun 2008 Tentang ITE adapun Peraturan Pemerintah Nomor 82 Tahun 2012 Tentang Penyelenggaraan Sistem dan Transaksi Elektronik. Transaksi Elektronik diatur dalam Pasal 40 sampai dengan Pasal 51 yang didalamnya memuat tentang lingkup penyelenggaraan transaksi elektronik, persyaratan penyelenggaraan transaksi elektronik dan persyaratan transaksi elektronik.

\subsection{Tanda Tangan Elektronik}

Hukum positif Indonesia belum pernah memberikan definisi terhadap kata tanda tangan yang sesungguhnya mempunyai dua fungsi hukum dasar, yaitu: (1) Tanda identitas penandatangan, dan (2) Sebagai tanda persetujuan dari penandatangan terhadap kewajiban-kewajiban yang melekat pada akta. Berdasarkan kedua fungsi hukum tersebut maka dapat ditarik suatu definisi sebagai berikut, tanda 
tangan adalah sebuah identitas yang berfungsi sebagai tanda persetujuan terhadap kewajibankewajiban yang melekat pada kita.

Menurut Efa Laela Fakhriah, keharusan adanya tanda tangan tidak lain bertujuan untuk membedakan akta yang satu dari akta yang lainnya atau akta yang dibuat orang lain. Jadi fungsi tanda tangan tidak lain adalah untuk memberi ciri atau untuk mengindividualisir sebuah akta. Dalam Kamus Besar Bahasa Indonesia (KBBI), tanda tangan adalah tanda sebagai lambang nama yang di tuliskan dengan tangan oleh orang itu sendiri sebagai penanda pribadi (telah menerima dan sebagainya). Tanda tangan juga merupakan suatu tulisan yang dijadikan seseorang untuk mengesahkan atau mendeklarasikan sesuatu yang bentuknya dibuat sesuai keinginan masing-masing orang tersebut dengan suatu susunan (huruf) tanda berupa tulisan serta lengkungan-lengkungan yang layaknya seperti sebuah tulisan.

Tanda tangan elektronik (Digital Signature) adalah pengganti tanda tangan secara manual yang bersifat elektronik dan mempunyai fungsi sama dengan tanda tangan manual. Tanda tangan elektronik merupakan rangkaian bit yang diciptakan dengan melakukan komunikasi elektronik melalui fungsi hashsatu arah dan kemudian melakukan enkripsi pesan dengan kunci pribadi pengirim.

Berdasarkan ketentuan Pasal 1 angka 12 Undang-Undang Nomor 11Tahun 2008 tentang Informasi dan Transaksi Elektronik, yang dimaksudkan dengan tanda tangan elektronik adalah tanda tangan yang terdiri atas informasi elektronik yang dilekatkan terasosiasi atau terkait dengan informasi elektronik lainnya yang digunakan sebagai alat verifikasi dan autentikasi. Terasosiasi yang dimaksud adalah informasi elektronik yang ingin ditandatangani menjadi data pembuatan tanda tangan elektronik, sehingga antara tanda tangan elektronik dan informasi elektronik yang ditanda tangani menjadi erat hubungannya berarti seperti fungsi kertas.

Tanda tangan elektronik bukan merupakan gambar digital dari tanda tangan yang dibuat oleh tangan atau tanda tangan yang diketik. Tanda tangan elektronik dapat digunakan untuk tujuan yang sama seperti tanda tangan yang ditulis oleh tangan, yang didalamnya mungkin menandakan surat tanda terima, persetujuan atau tujuan keamanan informasi penting.

Tandatangan elektronik mempunyai beberapa sifat yakni: (1) Otentik, tak bisa, sulit ditulis atau ditiru oleh orang lain. Pesan dan tanda tangan pesan tersebut juga dapat menjadi barang bukti, sehingga penandatangan tak bisa menyangkal bahwa dulu ia tidak pernah menandatanganinya. Otentisitas sangat diperlukan dalam berkomunikasi di internet sebab pertanggungjawaban suatu subjek hukum tergantung pada kejelasan identitasnya. Kebutuhan akan otentisitas ini dapat tercapai dengan menggunakan sertifikat digital; (2) Hanya sah untuk dokumen atau pesan itu saja atau salinannya yang sama persis. Tanda tangan itu tidak bisa dipindahkan ke dokumen lainya, meskipun dokumen lain itu hanya berbeda sedikit. Ini juga berarti bahwa jika dokumen itu diubah, maka tanda tangan elektronik dari pesan tersebut tidak lagi sah; dan (3) Dapat diperiksa dengan mudah, termasuk oleh pihak-pihak yang belum pernah bertatap muka langsung dengan penadatangan.

Tanda tangan elektronik dapat diklasifikasikan menjadi :

a. Tanda Tangan Elektronik (Biasa)

Tanda tangan elektronik biasa adalah tanda tangan yang ditujukan kepada si penandatangan, yang dilakukan dengan media elektronik. Seperti suatu tanda tangan konvensional (tertulis) yang kemudian di-scan. Kemudian hasil scan tersebut akan menjadi suatu informasi elektronik, biasanya berupa suatu file gambar, ditempelkan (paste) pada suatu dokumen elektronik. Hal tersebut sudah termasuk dalam ruang lingkup tanda tangan elektronik biasa.

b. Tanda Tangan Elektronik yang Aman

Tanda tangan elektronik yang aman merupakan suatu tanda tangan elektronik yang harus memenuhi persyaratan tertentu, sehingga dapat dalam konteks kesamaannya, dapat dipersamakan dengan tanda tangan konvensional.

\section{METODE PENELITIAN}

\subsection{Jenis dan Sumber Bahan Hukum}

Jenis Penulisan ini bersifat yuridis normatif yang mengacu pada perarturan perundang-undangan dan sumber data digunakan dalam penelitian ini adalah data sekunder dimana data yang diperoleh berasal dari hasil penelitian kepustakaan (library research) berupa dokumen, buku-buku dan undang-undang yang merupakan sumber data yang adayang terkait dengan topik permasalahan yang diteliti. 


\subsection{Teknik Pengumpulan Data}

Untuk memperoleh data yang dibutuhkan Penulis menggunakan studi pustaka (library research) yaitu mengumpulkan data dengan cara membaca dan menelusuri literatur-literatur seperti dokumen, bukubuku, dan sumber yang berasal dari internet atau data-data yang bersifat ilmiah yang berhubungan dengan topik permasalahan yang diteliti.

\subsection{Analisis Data}

Analisis data dalam penelitian ini menggunakan analisis kualitatif, artinya menguraikan data yang diolah secara rinci kedalam bentuk kalimat-kalimat. Berdasarkan hasil analisis ditarik kesimpulan secara dedukatif, yaitu cara berpikir yang didasarkan pada fakta-fakta yang bersifat umum untuk kemudian ditarik suatu kesimpulan bersifat khusus.

\section{HASIL DAN PEMBAHASAN}

\subsection{Kedudukan dan kekuatan hukum dari tandatangan elektronik dalam perjanjian.}

Transaksi elektronik yang menggunakan tanda tangan elektronik tentunya sangat memudahkan terutama jika kedua belah pihak berada di negara yang berbeda misalnya warga negara Amerika melakukan perjanjian dengan warga negara Indonesia. Namun jika salah satu pihak melakukan wanprestasi para pihak akan kesulitan untuk menyelesaikan perkara tersebut karena memiliki dua sistem hukum yang berbeda yaitu sistem hukum di Amerika dan sistem hukum di Indonesia. Sehingga untuk menghindari hal tersebut, sebelum membuat perjanjian para pihak membuat Memorandum of Understanding (MoU).

MoU merupakan suatu nota atau surat dimana masing-masing pihak melakukan penandatanganan MoU sebagai suatu pedoman awal tanda adanya suatu kesepahaman diantara mereka. MoU hanya berisikan hal-hal pokok saja merupakan suatu perjanjian pendahuluan, yang akan mengatur dan menjabarkan detail isi yang akan dimasukkan dalam kontrak atau perjanjian. Dalam MoU juga dapat berisikan bentuk penyelesaian seperti sistem hukum mana yang akan para pihak gunakan. Sehingga apabila terjadi suatu perkara dapat dengan mudah diselesaikan sesuai dengan sistem hukum yang terdapat dalam MoU.

Seiring dengan perkembangan kemajuan dibidang teknologi informasi dan telekomunikasi, berkembang pula hal-hal atau cara-cara yang dapat dijadikan sebagai alat bukti dalam hubungan keperdataan yang terjadi di masyarakat modern ini dengan munculnya berbagai macam transaksi modern. Pembuktian merupakan tahap terpenting dalam penyelesaian perkara di pengadilan, karena bertujuan untuk membuktikan telah terjadinya suatu peristiwa atau hubungan hukum tertentu yang dijadikan dasar mengajukan gugatan ke pengadilan. Melalui tahap pembuktianlah hakim akan memperoleh dasar-dasar untuk menjatuhkan putusan dalam menyelesaian suatu perkara.

Alat bukti elektronik semakin banyak muncul dalam praktiknya di masyarakat, misalnya e-mail, pemeriksaan saksi menggunakan video teleconference, sistem layanan pesan singkat (SMS: short message system), hasil rekaman kamera tersembunyi (CCTV: closed circuit tele vision), informasi elektronik, tiket elektronik, data/dokumen elektronik dan sarana elektronik lainnya sebagai media penyimpan data. Sebuah instrumen yang dapat digunakan untuk menentukan keaslian atau keabsahan suatu bukti elektronik berupa dokumen atau informasi elektronik adalah tanda tangan elektronik. Tanda tangan elektronik bertujuan untuk memastikan otentitas dari sebuah dokumen dalam suatu transaksi elektronik dan menjamin keutuhan isi dari dokumen tersebut tidak berubah selama proses pengiriman.

Jaminan authenticity dapat dilihat dari adanya hash function dalam sistem tanda tangan elektronik, sehingga penerima data dapat melakukan perbandingan hash value.Apabila hash value-nya sama dan sesuai, maka data tersebut benar-benar otentik dan tidak pernah terjadi suatu tindakan yang sifatnya merubah data tersebut pada saat proses pengiriman, sehingga terjamin authenticity-nya. Sebaliknya, apabila tidak sama atau ada perubahan pada hash value, maka patut dicurigai dan langsung dapat disimpulkan bahwa penerima menerima data yang telah dimodifikasi.

Tanda tangan elektronik memiliki kekuatan hukum sama dengan tanda tangan konvensional yang menggunakan tinta basah dan meterai. Dalam UU ITE Pasal 11 disebutkan bahwa tanda tangan elektronik memiliki kekuatan hukum dan akibat hukum yang sah selama memenuhi persyaratan sebagai berikut:

a. Data pembuatan Tanda Tangan Elektronik terkait hanya kepada Penanda Tangan. 
b. Data pembuatan Tanda Tangan Elektronik pada saat proses penandatanganan elektronik hanya berada dalam kuasa Penanda Tangan.

c. Segala perubahan terhadap Tanda Tangan Elektronik yang terjadi setelah waktu penandatanganan dapat diketahui.

d. Segala perubahan terhadap Informasi Elektronik yang terkait dengan Tanda Tangan Elektronik tersebut setelah waktu penandatanganan dapat diketahui.

e. Terdapat cara tertentu yang dipakai untuk mengidenti-fikasi siapa penandatangannya.

f. Terdapat cara tertentu untuk menunjukkan bahwa Penanda Tangan telah memberikan persetujuan terhadap Informasi Elektronik yang terkait.

Apabila dalam pembuatan tanda tangan elektronik sudah sesuai dengan persayaratan dan prosedur yang disebutkan dalam Pasal 11 UU ITE maka tanda tangan tersebut sudah memiliki kekuatan hukum dan akibat hukum yang sah.

\subsection{Tingkat keamanan bagi konsumen dalam penggunaan tanda tangan elektronik dalam transaksi elektronik}

Penggunaan tanda tangan elektronik dalam proses pembentukan perjanjian atau kontrak $(e-$ commerce), akan memudahkan mekanisme pembuktian dalam kasus perdata. Hal ini karena dengan memberikan tanda tangan elektronik pada data elektronik yang dikirimkan, maka akan dapat ditunjukan dari mana data elektronik tersebut sesungguhnya berasal. Terjaminnya integritas pesan tersebut dapat terjadi karena keberadaan sertifikat elektronik (digital certificate).

Suatu sertifikat elektronik berisi informasi mengenai pengguna antara lain; identitas, kewenangan, kedudukan hukum, dan status dari pengguna. Sertifikat elektronik memiliki berbagai tingkatan yang menentukan berapa besar kewenangan yang dimiliki oleh pengguna. Sebagai contoh apabila suatu perusahaan akan melakukan suatu perbuatan hukum maka sertifikat elektronik yang dipergunakan adalah yang dimiliki oleh direksi perusahaan tersebut. Dengan keberadaan sertifikat elektronik, maka pihak ketiga yang berhubungan dengan pemegang sertifikat elektronik dapat merasa yakin bahwa suatu pesan adalah benar berasal dari pengguna tersebut.

Kewajiban penggunaan sertifikat elektronik pada layanan publik ini telah diamanatkan pada Peraturan Pemerintah Nomor 82 Tahun 2012 tentang Penyelenggara Sertifikasi Elektronik (PP PSTE) Pasal 59 ayat (1) bahwa Penyelenggara Sistem Elektronik untuk pelayanan publik wajib memiliki Sertifikat Elektronik. Lebih lanjut, sesuai dengan amanat PP PSTE (Pasal 64 ayat (2)), Penyelenggara Sertifikasi Elektronik (PSrE) Induk sebagai "trust anchor" penerbitan identitas online atau sertifikat elektronik diselenggarakan oleh Kemenkominfo. Kemudian PSrE Induk menjamin identitas PSrE Berinduk dengan menerbitkan sertifikat elektronik bagi PSrE Berinduk yang memenuhi persyaratan teknis. Kemudian PSrE Berinduk menjamin identitas masyarakat dan pemerintah dengan menerbitkan sertifikat elektronik (identitas elektronik) bagi mereka. Sertifikat elektronik diperoleh atas dasar aplikasi kepada Certification Authority (CA) oleh pengguna (subscriber).

Certificate Authority (CA) merupakan sebuah lembaga yang berperan dalam mengeluarkan sertifikat elektronik. Pengguna sertifikat tersebut meliputi perusahaan, instansi, atau perorangan setelah melewati proses verifikasi. CA bertanggung jawab atas penyimpanan informasi. Masing-masing CA dibekali Certification Practice Statement (CPS). Selain itu CA juga mengesahkan pasangan kunci publik dan kunci privat milik orang tersebut. Prosessertifikasi untuk mendapatkan pengesahan dari CA dapat dibagi menjadi tiga tahap :

1. Pelanggan atau subscriber membuat sendiri pasangankunci privat dan kunci publiknya dengan menggunakan software yang ada di dalam komputernya.

2. Menunjukan bukti-bukti identitas dirinya sesuai dengan yang disyaratkan CA.

3. Membuktikan bahwa dia mempunyai kunci privat yang dapat dipasangkan dengan kunci publik tanpa harus memperlihatkan kunci privatnya.

Beberapa lembaga CA yang paling populer, antara lain Verisign, GEoTrust, Thawte, dan Entrust, GlobalSign, Sivion, dan Comodo. Masing-masing CA menerbitkan sertifikat dengan unsur sama. Perbedaannya terletak pada tingkat kepercayaan masyarakat. Semisal Verisign; lembaga ini sudah membuktikan dedikasi dalam mengeluarkan sertifikat elektronik. Secara teknik, jelas teruji kemampuannya.

Perlindungan terhadap konsumen baik dipandang secara material maupun formal semakin terasa sangat penting, mengingat semakin berkembangnya ilmu pengetahuan dan teknologi dalam rangka 
mencapai sasaran usaha. Menurut Celina Tri Siwi Kristiyanti. Konsumen pada umumnya akan merasakan dampaknya, dengan demikian upaya-upaya untuk memberikan perlindungan yang memadai terhadap kepentingan konsumen merupakan suatu hal yang penting dan mendesak terutama di Indonesia mengingat kompleknya permasalahan yang menyangkut perlindungan konsumen, lebih-lebih menyongsong era perdagangan bebas yang akan datang.

Sedangkan untuk perlindungan konsumen menurut Janus Sidabalok dapat dilihat dari dua aspek, yaitu aspek keperdataan dan aspek kepidanaan. Dalam aspek keperdataan membicarakan sejumlah hak konsumen yang merupakan bagian dari masyarakat dan perlu mendapat perlindungan hukum. Kesepakatan antara kedua belah pihak yaitu produsen dan konsumen, tentunya melalui suatu peristiwa hukum yang disebut perjanjian. Jika seorang konsumen dilanggar haknya dan menimbulkan kerugian baginya, konsumen dapat mengajukan tuntutan gugatan untuk mendapatkan kembali haknya itu. Persoalan untuk mendapatkan penggantian kerugian adalah masalah hukum perdata, sehingga mulai dari penegakan hukum atas hak-hak konsumen, penggunaan ketentuan- ketentuan dan institusi dapat ditempuh secara perdata. Karena itulah perlindungan konsumen dapat dimasukkan ke dalam kelompok hukum perdata.

Perlindungan konsumen diatur dalam Undang-Undang Nomor 8 tahun 1999. Undang-Undang ini belum mengacu pada perkembangan teknologi dan informasi, sehingga tentang keamanan tanda tangan elektronik belum disebutkan. Namun dalam undang- undang perlindungan konsumen menyebutkan secara umum mengenai jaminan atas keselamatan, kenyamanan, dan keamanan konsumen. Dalam aspek kepidanaan, apabila perbuatan produsen yang menimbulkan kerugian kepada konsumen baik kerugian kecil maupun besar dapat berdimensi kejahatan. Artinya perbuatan produsen merugikan atau bahkan melanggar hak konsumen yang bertentangan dengan norma-norma hukum pidana dan dapat dikategorikan sebagai tindak pidana, sehingga peristiwa tersebut harus diselesaikan sesuai dengan hukum pidana dan memakai instrument pidana.

Menurut UU ITE yang temasuk tindak pidana informasi dan transaksi elektrnonik adalah:

(1) Konten Ilegal/ Illegal Content ( Pasal 27, 28, dan 29)

(2) Akses Ilegal/ Illegal Access (Pasal 30)

(3) Penyadapan Ilegal/ Illegal Interception (Pasal 31)

(4) Gangguan Data/ Data Interference (Pasal 32)

(5) Gangguan Sistem/ System Interference (Pasal 33)

(6) Penyalahgunaan Perangkat/ Misuse of Devices (Pasal 34)

(7) Penipuan dan Pemalsuan yang berkaitan dengan komputer/Computer Related Fraud and Forgery (Pasal 35)

Sedangkan ancaman hukuman pidana bagi yang melanggar Undang-Undang tersebut adalah:

(1) Pidana Penjara paling lama 6 tahun hingga 12 tahun dan/atau denda anraea Rp 1.000.000.000,hingga Rp 2.000.000.000,- (Pasal 45)

(2) Pidana Penjara paling lama 6 tahun hingga 8 tahun dan/atau denda anraea Rp 600.000.000,hingga Rp 800.000.000,- (Pasal 46)

(3) Pidana Penjara paling lama 10 tahun dan/atau denda paling banyak Rp 800.000.000,- (Pasal 47)

(4) Pidana Penjara paling lama 8 tahun hingga 10 tahun dan/atau denda antara Rp 1.000.000.000,hingga Rp 5.000.000.000,- (Pasal 48)

(5) Pidana Penjara paling lama 10 tahun dan/atau denda paling banyak Rp 10.000.000.000,- (Pasal 49 dan Pasal 50)

(6) Pidana Penjara paling lama 12 tahun dan/atau denda paling banyak Rp 12.000.000.000,- (Pasal 51)

(7) Hukuman pidana sebagaimana yang dimaksud dalam Pasal 27 Ayat (1) yang menyangkut kesusilaan atau eksploitasi seksual terhadap anak dikenakan pemberatan sepertiga dari pidana pokok (Pasal 52 Ayat [1])

(8) Perbuatan sebagaimana dimasud dalam Pasal 30 sampai dengan Pasal 37 yang ditujukan terhadap computer dan/atau system elektronik serta informasi elektronik dan/atau dokumen elektronik milik Pemerintah dan/atau yang digunakan untuk layanan publik dipidana dengan pidana pokok ditambah sepertiga (Pasal 52 Ayat [2])

(9) Perbuatan sebagaimana dimasud dalam Pasal 30 sampai dengan Pasal 37 yang ditujukan terhadap komputer dan/atau sistem elektronik serta informasi elektronik dan/atau dokumen elektronik milik Pemerintah dan/atau badan strategis termasuk dan tidak terbatas pada lembaga pertahanan, bank sentral, perbankan, keuangan, lembaga internasional, otoritas penerbangan diancam dengan pidana 
maksimal ancaman pidana pokok masing-masing Pasal ditambah dua pertiga (Pasal 52 Ayat [3])

(10) Perbuatan sebagaimana dimaksud dalam Pasal 27 sampai dengan 37 dilakukan oleh korporasi dipidana dengan pidana pokok ditambah dua pertiga (Pasal 52 ayat [4])

Sedangkan mengenai hukum acara yang digunakan untuk memeriksa dan mengadili perkara tindak pidana pada umumnya, namun oleh karena tindak pidana ini menggunakan sarana teknologi canggih diperlukan adanya ketelitian dan kecermatan bagi hakim dalam menggali fakta-fakta hukum yang diperoleh dipersidangan selain dari seorang ahli.

\section{KESIMPULAN DAN SARAN}

\subsection{Kesimpulan}

1. Kedudukan mengenai tanda tangan elektronik sudah diatur secara jelas dalam Undang-Undang Nomor 11 Tahun 2008 tentang Informasi dan Transaksi Elektronik, dan juga dalam Peraturan Pemerintah Nomor 82 Tahun 2012 tentang Penyelenggaraan Sistem dan Transaksi Elektronik. Kekuatan hukum dari tanda tangan elektronik sebagai alat bukti adalah berlandaskan kepada Pasal 11 Undang-Undang Nomor 11 Tahun 2008 tentang Informasi dan Transaksi Elektronik. UndangUndang ini memberikan pengakuan secara tegas bahwa tandatangan elektronik memiliki kekuatan hukum dan akibat hukum selama tanda tangan elektronik mengikuti persyaratan yang disebutkan dalam Pasal 11 UU ITE yang merupakan persyaratan minimum dan harus dipenuhi dalam setiap pembuatan tanda tangan elektronik.

2. Tingkat keamanan dari tanda tangan elektronik akan terjamin keamanannya apabila pesan tersebut mempunyai sertifikat elektronik berisi informasi atau identitas dari pengguna. Sertifikat elektronik diperoleh atas dasar aplikasi kepada Certification Authority (CA) oleh pengguna (subscriber). Perlindungan konsumen dapat dilakukan dalam dua aspek, yaitu aspek hukum keperdataan dan juga aspek hukum kepidanaan sesuai dengan duduk perkara yang ada.

\subsection{Saran}

1. Pemerintah kiranya membuat Undang-Undang yang lebih jelas dan hanya pembahasan pokok masalah mengenai transaksi khususnya mengenai tanda tangan elektronik dengan menggunakan aturan Undang-Undang di Indonesia sehingga dapat digunakan dan kiranya Pemeritah juga melakukan pelatihan atau seminar guna memperkenalkan penggunaaan tanda tangan elektronik kepada instansi instansi terkait dan masyarakat.

2. Penulis menyarankan kepada masyarakat kiranya sebelum membuat perjanjian dalam bentuk transaksi elektronik harus memahami terlebih dahulu dasar-dasar hukum dari transaksi elektronik dan juga dapat mengetahui kemajuan teknologi yang digunakannya dalam pemakaian tanda tangan elektronik, sehingga kelak masyarakat tidak akan mengalami kesusahan saat proses pengiriman atau pelaksanaanya.

\section{DAFTAR PUSTAKA}

Abdul Halim Barkatulah.2009.Perlindungan Hukum Bagi Konsumen Dalam Transaksi E-commerce Lintas Negara di Indonesia. Pascasarjana FH UII. Yogyakarta

Adami Chazawi dan Ardi Ferdian. 2015. Tindak Pidana Informasi Dan Transaksi Elektronik (Penyerangan Terhadap Kepentingan Hukum Pemanfaatan Teknologi Informasi dan Transaksi Elektonik). Media Nusa Creative. Malang

Ahmadi Miru dan Sakka Pati. 2016. Hukum Perikatan: Penjelasan Makna Pasal 1233 sampai 1456 $B W$. Rajawali Pers. Jakarta.

Celina Tri Siwi Kristiyanti.2008.Hukum Perlindungan Konsumen. Sinar Grafika. Jakarta.

Efa Laela Fakhtiah. 2017. Bukti Elektronik dalam Sistem Pembuktian Perdata. PT Refika Aditama. Bandung.

Gunawan Widjaja dan Ahmad Yani.2008. Hukum Tentang Perlindungan Konsumen.PT Gramdia.Jakarta

Janus Sidabalok.2006. Hukum Perlindungan Konsumen di Indonesia. PT Citra Adtya Bakti. Bandung Mariam Darus Badrulzaman et.al. 2001. Kompilasi Hukum Perikatan. PT Citra Aditya Bakti. Bandung. M. Arsyad Sanusi.2005. Hukum dan Teknologi Informasi. The Indonesian Rearch. Jakarta 
M. Arsyad Sanusi.2007.Konvergensi Hukum dan Teknologi Informasi (Sebuah Torehan EmpirisYuridis).The Indonesian Rearch. Jakarta

M. Suyanto.2003. Strategi Periklanan Pada E-Commerce Perusahaan Top Dunia. Andi. Yogyakarta Muljani Kartini dan Widjaja Gunawan. 2003. Perikatan Pada Umumnya.PT Raja Grafindo. Jakarta Siswanto Sunarso. 2009. Hukum Informasi Dam Transaksi Elektronik, Studi Kasus: Prita Mulyasari. Rineka Cipta. Jakarta.

Soemarno Partodihardjo.2009. Tanya Jawab Sekitar Undang-Undang No.11 Tahun 2008 Tentang Informasi Dan Transaksi Elektronik. Gramedia Pustaka Utama.Jakarta

Soerjono Soekanto.2004. Pengantar Penelitian Hukum. UI Press.Jakarta

Wirjono Prodjodikoro.2000. Azas-azas Hukum Perjanjian. Penerbit Mandar Maju. Bandung. 